Copying. This journal is registered with the Copyright Clearance Center, 21 Congress Street, Salem, Mass. 01970. Organizations in the USA who are also registered with C.C.C. may therefore copy material (beyond the limits permitted by sections 107 and 108 of the US copyright law) subject to payment to C.C.C. of the per-copy fee of $\$ 05.00$. This consent does not extend to multiple copying for promotional or commercial purposes. Code 0007-1145/86/0055-0056 \$05.00.

ISI Tear Service, 3501 Market Street, Philadelphia, Pennsylvania 19104, USA, is authorized to supply single copies of separate articles for private use only.

For all other use, permission should be sought from Cambridge or the American Branch of Cambridge University Press.

The Proceedings of the Nutrition Society, published by the Cambridge University Press, in part record meetings of the Symposium type, at which experts in a particular field are invited by Council to make contributions on specific parts of it and at which general discussion follows these invited contributions. The contributions will be published in extenso; such summaries of the ensuing discussions as circumstances warrant may also be published. The Society also holds scientific meetings at which papers are communicated by members and others on original work carried out by them. It is proposed at present to publish summaries of the papers read at each meeting, each communication being recorded in the Society's Proceedings by means of an abstract not exceeding in length 400 words or the equivalent space in print. The Proceedings are published three times a year.

The subscription to the Proceedings is $£ 60.00$ net (US $\$ 145.00$ in USA and Canada). Single issues are $£ 22.00$ (US $\$ 55.00$ in the USA and Canada) each; postage extra.

continued from back cover

Gill. M., Siddons R. C., Beever D. E. \& Rowe J. B. Metabolism of lactic acid isomers in the rumen of silage-fed sheep

Latunde-Dada G. O. \& Nfale R. J. Pigeon (Columba L.) meat iron solubility and availability for absorption in rats

LATUNDE-DADA G. O. \& NEALE R. J. Effect of soya-bean protein on meat iron solubility and absorption in rats

Batterham E. S., Lowe R. F., Darnell R. E. \& Major E. J. Availability of lysine in meat meal, meat and bone meal and blood meal as determined by the slope-ratio assay with growing pigs, rats and chicks and by chemical techniques

Batterham E. S., Darnell R. E., Herbert L. S. \& Major E. J. Effect of pressure and temperature on the availability of lysine in meat and bone meal as determined by slope-ratio assays with growing pigs, rats and chicks and by chemical techniques

BATES C. J. \& FULLER N. J. The effect of riboflavin deficiency on methylenetetrahydrofolate reductase $(\mathrm{NADPH})(E C 1.5 .1 .20)$ and folate metabolism in the rat 


\section{The British Journal of Nutrition}

\section{Volume 55 No. 2 March 1986}

\section{CONTENTS}

Papers of direct relevance to CLINICAL AND HUMAN NUTRITION

Blakeborough Petter, Gurkr Michael I. \& Salter Dallyn N. Digestion of the zinc in human milk, cow's milk and a commercial babyfood: some implications for human infant nutrition

mutanen Marja, Koivistoinen Pekka, Morris Virginia C. \& Levander Orville A. Nutritional availability to rats of selenium in four seafoods: crab (Callinectes sapidus), oyster (Crassostrea virginica), shrimp (Penaeus duorarum) and Baltic herring (Clupea harengus)

Johansson U., Johnsson F., Joelsson B., Berglund M. \& Åkesson B. Selenium status in patients with liver cirrhosis and alcoholism

Ekanayake Athula \& Nelson Philip E. An in vitro method for estimating biologically available vitamin $B_{6}$ in processed foods

SANDberg AnN-SOFIE, ANDERSgon Henrik, Kivistö Barbro \& Sandström Brittmarie. Extrusion cooking of a high-fibre cereal product. 1. Effects on digestibility and absorption of protein, fat, starch, dietary fibre and phytate in the small intestine

Kivistö Barbro, Andersson Henrix, Cederblad Gitien, SANDBerg Ann-Sofie \& SANDSTRÖM BRITTMARIE. Extrusion cooking of a high-fibre cereal product. 2. Effects on apparent absorption of zinc, iron, calcium, magnesium and phosphorus in humans

WyatT G. M., Bayliss C. E. \& Holcroft J. D. A change in human faecal flora in response to inclusion of gum arabic in the diet

NELSON MICHAEL. The distribution of nutrient intake within families

Fairweather-Tait Susan J. \& Minski Margaret J. Studies on iron availability in man, using stable isotope techniques

Stanley John C.. Lambadarios Jacqueline A. \& Newsholme Eric A. Absence of effects of dietary wheat bran on the activities of some key enzymes of carbohydrate and lipid metabolism in mouse liver and adipose tissue

Bydlowski S. P., Stivaletti V. L. G. \& Douglas C. R. Biochemical observations on rat aorta: interaction of dietary protein and cholesterol

Papers on GENERAL NUTRITION

Bet. J. G., Pirie B. J. S., Adron J. W. \& Cowey C. B. Some effects of selenium deficiency on glutathione peroxidase $(E C$ 1.11.1.9) activity and tissue pathology in rainbow trout (Salmo gairdneri)

Dixon R. M. \& NOLAN J. V. Nitrogen and carbon flows between the caecum, blood and rumen in sheep given chopped lucerne (Medicago sativa) hay

JACKSON N., GibSON S. W. \& StEVEnSON M. H. Effects of short- and long-term feeding of zinc oxide-supplemented diets on the mature female domestic fowl with special reference to tissue mineral content

Kroonen J. E. G. M., Verstegen M. W. A., Boon J. H. \& VAN der Hel W. Effect of infection with lungworms (Dictyocaulus viviparus) on energy and nitrogen metabolism in growing calves

IVAn M., Veira D. M. \& Kelleher C. A. The alleviation of chronic copper toxicity in sheep by ciliate protozoa

Jackson Malcolm J., Holt Daphne, WebB Michael \& Carter Nicholas D. Physiological zinc-binding proteins of medium molecular weight in the rat gut

Goswami Bhabesh C. \& Barua Arun B. Metabolism of dehydroretinyl ester in white leghorn chicks

amaning-K warteng K., Kellaway R. C., Leibholz Jane \& Kirby A. C. Rumen degradation and fractional outflow rates of nitrogen supplements given to cattle eating sodium hydroxide-treated straw

(C) The Nutrition Society 1986

For Index of Authors see page facing inside back cover

CAMBRIDGE UNIVERSITY PRESS

The Pitt Building. Trumpington Street, Cambridge CB2 IRP

32 East 57th Street, New York, NY 10022, USA

10 Stamford Road, Oakleigh, Melbourne 3166, Australia

Printed in Great Britain by the University Press, Cambridge 